\title{
Pedogenic characteristics of soil in Melur block, Madurai district, Tamil Nadu in India: A case study
}

\author{
P. Ramamoorthy* \\ Department of Soils and Environment, Agricultural College and Research Institute, Madurai \\ -625104 (Tamil Nadu), India \\ P. Christy Nirmala Mary \\ Department of Soils and Environment, Agricultural College and Research Institute, Madurai \\ -625104 (Tamil Nadu), India \\ ${ }^{*}$ Corresponding author. Email: ramagri95@gmail.com
}

\section{How to Cite}

Ramamoorthy, P. and Mary, P.C.N. (2021). Pedogenic characteristics of soil in Melur block, Madurai district, Tamil Nadu in India: A case study. Journal of Applied and Natural Science, 13 (SI), 198 - 202. https://doi.org/10.31018/jans.v13iSI.2828

\begin{abstract}
Soil is an important source of human life and agricultural production. Studying on the pedon and its site characteristics pave the way for understanding the nature of soils and its utility. A study on pedological characterization of soils in Melur block, Madurai District (Tamil Nadu), was carried out during 2019-2020 using grid sampling with village map/cadastral maps. Soil mapping unitbased soil samples were collected in Chunampoor, Thuvarangulam, Poonjuthi and Veppapadupu and pedons were characterized as per the standard procedure. The results showed that soils were moderately deep to very deep in nature, ranging from 2.5 YR $3 / 6$ to 10YR 4/6. The soil texture varied from sandy clay loam to sandy clay with weak to moderate sub-angular blocky structure. The consistency of soil varied from slightly hard to very hard when dry, very friable to firm when moist, slightly sticky to very sticky and slightly plastic to very plastic in wet condition. The crops viz., paddy, sugarcane, banana, groundnut and vegetables were very suitable for such type of soil of the Madurai district.
\end{abstract}

Keywords: Colour, Consistency, Pedons, Plasticity, Soil survey, Texture

\section{INTRODUCTION}

Soil is an important source of nutrients, house for microorganisms, plant growth and support for all living things. Soils are formed from different rocks and minerals, and it takes millions of years to develop. Each soil has its own characteristics and its property, which affects on crop production. Soil taxonomy plays an important role in classifying soil and advocating its fertility and capability. Madurai is one of the historical cityin Tamil Nadu, India, and blessed with different soil typebased cropping systems and the Vaigai River to prop up the water supply (Karpagam et al., 2020).

Detailed knowledge on morphological characteristics and site characteristics viz., landscape positions, slope percentage, slope length, erosion status, erosion type, groundwater depth, physiography, presence of stoniness, gravel content, rock out crops are very important in arriving soil series under soil taxonomy procedure and derive interpretive groupings for land use planning
(Pinki et al., 2017). Hence the present study was undertaken in Melur block, Madurai District using a cadastral map to study the pedogenic characteristics of soils.

\section{MATERIALS AND METHODS}

\section{Study area}

The study area of Melur block, Madurai District of Tamil Nadu, India is having an area of 3057 ha is located between $10^{\circ} 03^{\prime} 36^{\prime \prime} \mathrm{N}$ latitude and $78^{\circ} 33^{\prime} 58^{\prime \prime} \mathrm{E}$ longitude (Fig. 1). The average elevation of the Madurai District, Melur block is $101 \mathrm{~m}$ above MSL. The length of the growing period (LGP) is > 120 days (Ramamurthy et al., 2009). The climate is semi-arid, the mean annual summer temperature ranges from $40^{\circ}$ $\mathrm{C}$ to $26.3^{\circ} \mathrm{C}$ and the mean annual winter temperature ranges from $29.6{ }^{\circ} \mathrm{C}$ to $18{ }^{\circ} \mathrm{C}$, with a mean annual maximum rainfall of $926.56 \mathrm{~mm}$ and minimum rainfall of $723.6 \mathrm{~mm}$. 


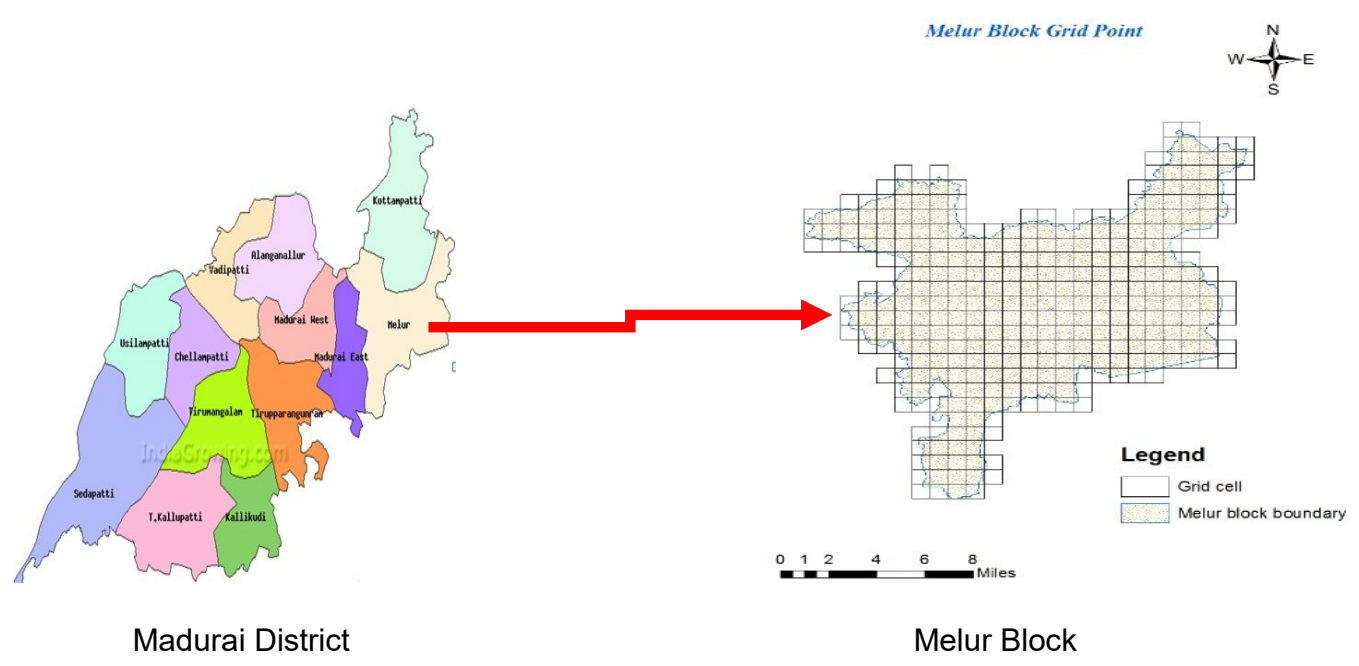

Fig. 1. Showing study area of Melur block, Madurai district of Tamil Nadu.

\section{Methodology}

A detailed soil survey was taken in the Melur block using a cadastral map with a 1: 5000 scale. Soil pedon sampling was done based on the traverse, grid sampling, road cuts, mini pits and profiles were excavated with the dimension of $2 \mathrm{~m} \times 2 \mathrm{~m} \times 2 \mathrm{~m}$ dimension from the benchmark sites. The site characteristics and morphological characteristics were taken from the profile excavated with the standard procedure at Chunampoor, Thuvarangulam, Poonjuthi and Veppapadupu by used standard procedure by Soil Survey Staff (2014).

\section{RESULTS AND DISCUSSION}

The results on the morphological characteristics of four soil pedons are presented in Table 1 and Plate 1. The pedons of 1,3,4 come under the red soil area and the pedon 2 comes under the black soil. Landscape slope $0-1 \%$ comes under nearly level to gently undulating (1$3 \%$ slope) and slight to severe erosion and moderately well-drained conditions.

\section{Horizon differentiation}

The pedons 1, 3 and 4 were classified as red soil and pedon 2 classified under black soil. The pedon 1 had $A p, B 11 t, B 12 t$ and $C$ horizons. The pedons 2,3 and 4 were $A p, B 1 t, B 2 t, B 3 t$, and $C ; A p, A B, B 1 t, B 2 t$ and $C$; $A p, B 11 t, B 12 t$ and $C$, respectively. Both red soil series and black soil had illuvial horizon represented as clay skins. A similar observation was made by Bhattacharjee et al. (1977) in the black soils of the Deccan plateau in India.

\section{Horizon boundary}

The horizon of the pedon in the red soil had unique topography of smooth throughout the profile, with the exception that wavy in Pedon4. In contrast to the above, black soil (pedon 2) had gradual and smooth bounda- ries with wavy in nature. The pedon had a heterogeneous transition of abrupt, clear, gradual with smooth and wavy topography. Abrupt, Smooth boundary formation might be due to ploughed soil nature and the gradual diffuse boundary was due to the absence of anthropogenic activities. A similar trend of results were observed inAlfisols in the Bako area of Ethiopia (Negassa and Gebrekidan, 2003).

\section{Soil depth}

The depth of the soils of the study area was moderately deep to very deep. Pedons 1 was moderately deep $(45 \mathrm{~cm}) ; 2,4$ are deep $(<100 \mathrm{~cm})$ and pedon 3 was categorised as very deep $(>100 \mathrm{~cm})$ in nature are presented in Table 1. The Solum depth reflected the balance between soil formation and soil loss by erosion in any area, governed by topography and slope. Soil depth varied from $48 \mathrm{~cm}$ to more than $155 \mathrm{~cm}$ across 4 pedons, indicating lesser erosion intensities. A similar type of the result of solum development has been reported in lower and mid plain contrast to upper pediment based on its landscape position of Rajasthan in Aravalli Range (Sharma et al., 2020).

\section{Colour}

The colour of the pedons varied with hue ranging from 2.5 YR to $7.5 Y R$, value 3 to 4 and chroma $4-6$ in red soil and hue $10 \mathrm{YR}$, values varied from 4 to 5 and chroma by 4 to 6 in black soil. 10YR hue was attributed due to the hydrated oxides of Fe formed under humid condition. Higher value and chroma observed in pedons might be due to the illuviation of $\mathrm{Fe}$ and Al. Low chroma indicated the aquic condition with poor drainage and immature parent material (Samrah et al., 2019). The colour of the soil changes come under the different soil properties based viz., mineralogy of soil, texture, chemical composition, soil moisture content and landscape position. The same findings of the 
Table 1. Morphological characteristics of pedons in Melur block of Madurai District.

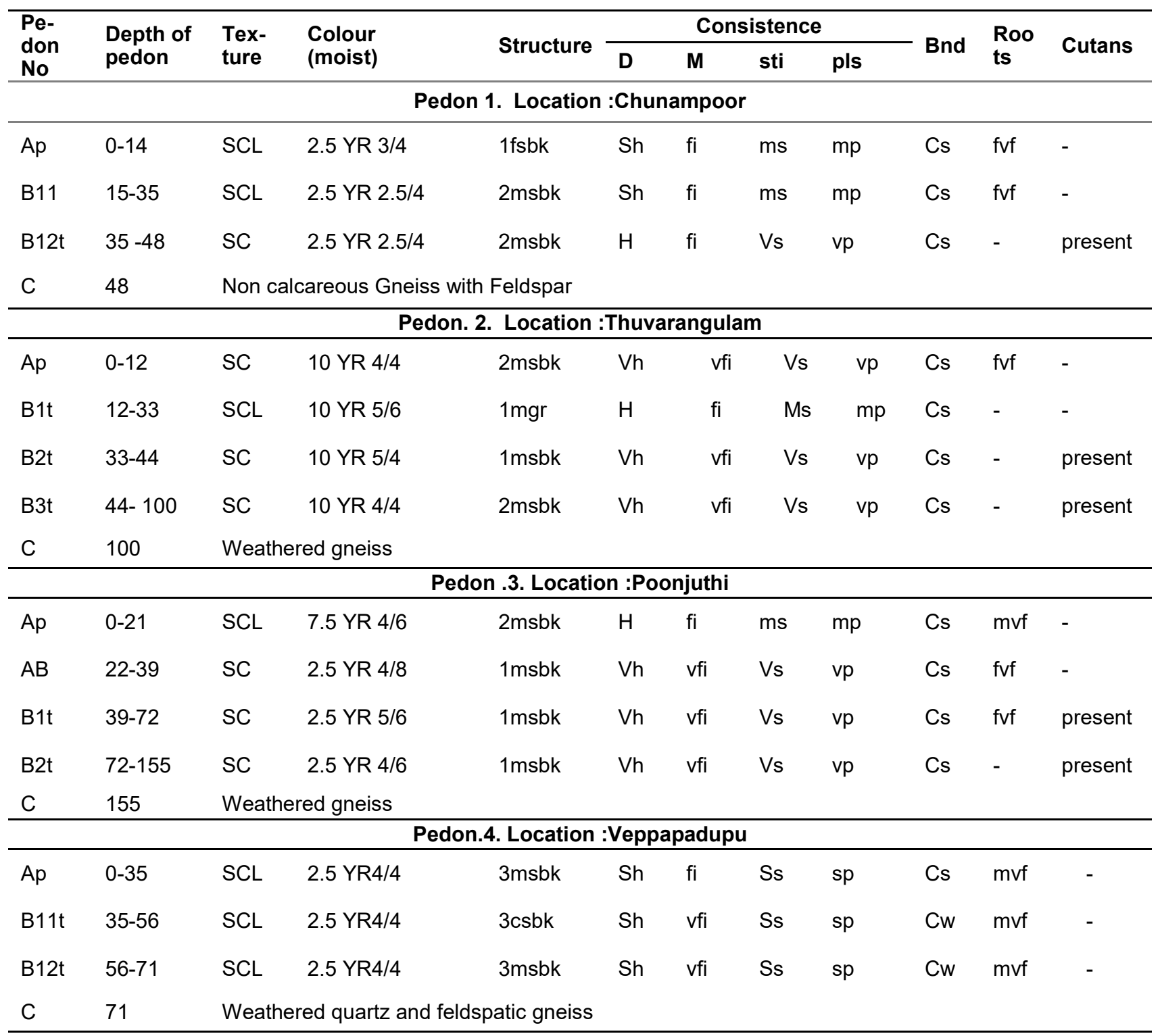

Abbrevations: i). Texture: S- sand, LS- loamy sand, SL-sandy loam, L-loam, SiL-siltyloam,Si-silt, ScL- sandy clay loam ,CL- clay loam, SiCL- silty clay loam, SC- sandy clay, SiC- silty clay loam, .C- clay. ii).Grade: 0-structureless, 1-weak, 2-moderate, 3-strong; Size; vf- very fine, f-fine, m-medium, c-coarse, vc-very coarse,iii). Type; gr-granular, cr-crumb, clr-columnar, pr-prismatic, pl-platy, abkangular blocky, sbk- subangular blocky, sg- single grain, m-massive, c-cloddy, iv). Dry; l-loose, s-soft, sh-slightly hard, h-hard, vh-very hard, eh-extremely hard.. Moist: I-loose, vfr-very friable, fr-friable, fi- firm, vfi -very firm, efi - extremely firm,. Stickiness: so - non sticky, ss- slightly sticky, ms- moderately sticky, vs- very sticky. Plasticity: po- non plastic, sp- slightly plastic, mp-moderately plastic, vp - very plastic; v). (Kd): Disseminated materials, Masses, Nodules, Concretions, vi). Roots: Quantity: $f-$ few (<1 per area), c- common (1-5), m- many (>5); Size: vf- very fine, f- fine, m-medium, c- coarse; vc- very coarse; Location (Loc): between peds (p), cracks (c), throughout (t); Shape(Shp): tubular/ irregular/ vesicular/ interstitial.

study are reported by Thangasamyet al. (2005) in the Sivagiri micro- watershed of Chittoor district in Andhra Pradesh.

\section{Soil texture}

The pedons of soil textural classes were classified from sandy clay loam to sandy clay. This soil textural variation was ascribed to differences in parent material composition, topography, in-situ weathering and clay translocation by eluviation and age of soils. A similar trend of results in textural variation from sandy clay loam to clay has interpreted the enrichment of clay in lower horizon due to illuviation or vertical migration of clay in saltaffected soils of Muktsar District of Punjab (Sandhu.,2017).

\section{Soil structure}

The soil structural pattern of pedons 1,2,3 varied from weak to moderate in grade, medium in size and subangular blocky nature and pedon 4 are strong in grade, medium in size and sub-angular blocky nature. The soil structural changes in pedons were due to higher clay 


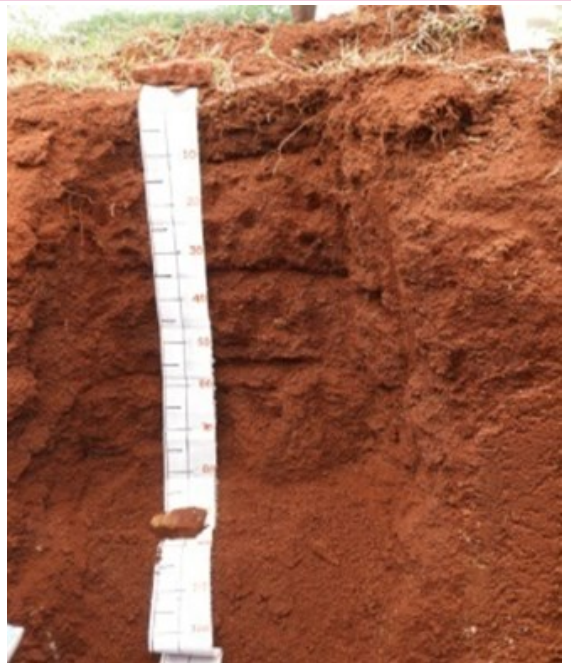

Pedon : 1

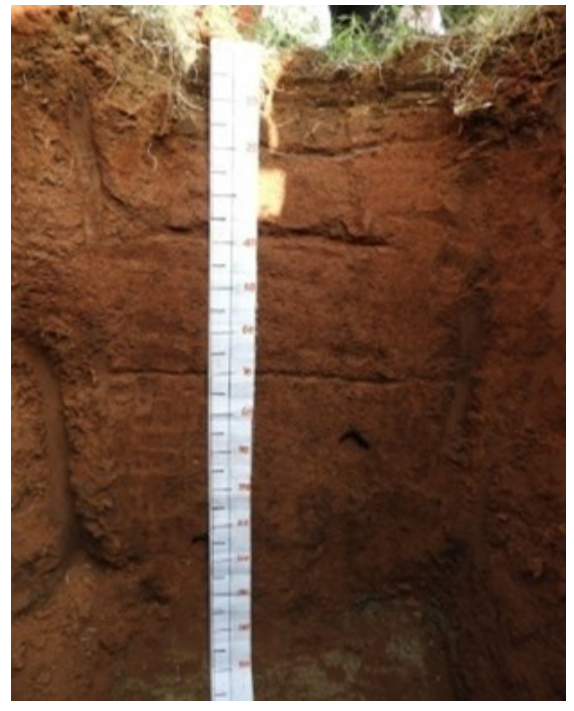

Pedon : 3

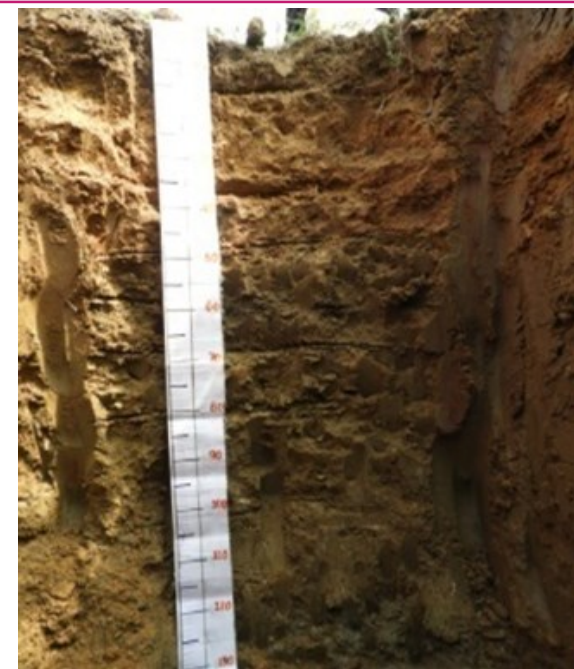

Pedon : 2

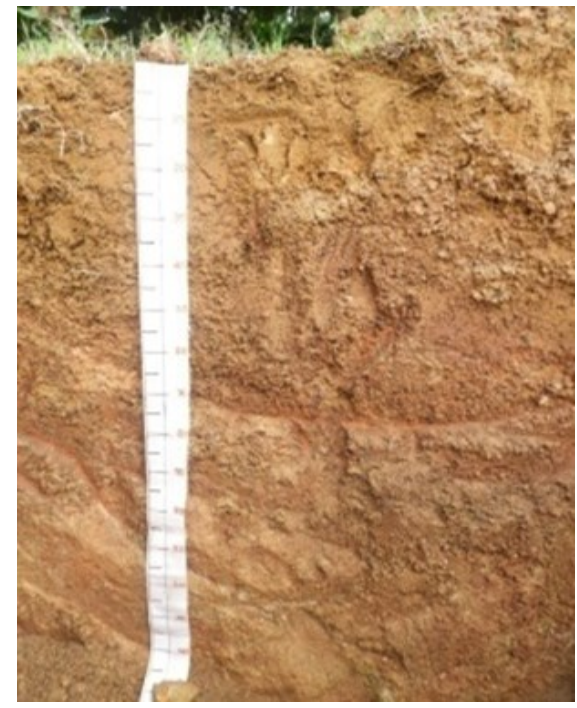

Pedon : 4

Plate 1. Pedon 1 -4.Eachprofileshowing the clearly smooth wavy boundary, roots and clay cutans.

content in the subsurface horizons when compared to surface horizons. A similar result of the low clay content of soil and low organic carbon content status was the reason to the weak structural formation of pedons in Alluvial Soils of Rajasthan in India(Samrahet al., 2019).

\section{Soil consistency}

The dry consistency ranged from slightly hard to very hard in nature and it might be due to the presence of fine-textured nature. The moist consistency had a range of firm to very firm, but the wet consistency ranged from slightly sticky to very sticky and slightly plastic to high plastic in nature. The same trend of results was also reported by Christy (2020) in the Vaigi river basin, Madurai District, Tamil Nadu in India.

\section{Roots and pores}

The fine, medium and tubular to irregular roots could be seen in the pedons due to the cultivation of coconut, banana, paddy and vegetables.

\section{Cutans}

Clay cutans with slickenside were seen in the pedons of 1 and 2, which might be due to the clay illuviation in Bt horizon. Similar results were observed on the west coast of southern Karnatakasoils(Patil and Kumar, 2014).

From the above results, it was confirmed that red soils are formed from granite gneiss parent material. They are dominated by kaolinite clay minerals in this area. The soil texture is sandy clay loam to clay loam, so these soils are more water holding capacity and water retention type are also. Soil comes under subangular blocky in nature, so the soil holds more nutrient, and thus plant-available nutrients are high. Hence they are highly suitable for field crops and all vegetables. 


\section{Conclusion}

The present study concluded that the morphological characteristics of soils of Melur block, Madurai District, are fully developed in nature and classified as Alfisol soil order of Irugur and Vygloam benchmark soil series. The crops viz., paddy, sugarcane, banana, groundnut and vegetables like okra, brinjal, tomato, chillies, cluster bean, cucumber etc. are very suitable for this area. Thus there is a substantial and significant addition of information to the existing knowledge on the soils of Melur block Madurai District.

\section{Conflict of interest}

The authors declare that they have no conflict of interest.

\section{REFERENCES}

1. Bhattacharjee, J.C., Landey, R.J. \& Kalbande, A.R., (1977). A new approach in the study of vertisol morphology. Journal of the Indian Society of Soil Science, 25(3), 221-232.

2. Christy NirmalaMary, P. (2020). Effect of topo sequence on morphological characteristics of soils from Alagar hills toe slope to Vaigi river basin, Madurai district, Tamil Nadu, India. International Journal of Agriculture and Biological Sciences, 4(5), 134-146.

3. Karpagam, S., Christy NirmalaMary, P., Kannan,S., Gurusamy, S., Shanmugasundaram, R. \& Ramamoorthy, P. (2020). Effect of climate change on morphological characteristics of the soils of Vaigai river basin, Alluvial tract, Madurai district, Tamil Nadu. Journal of Pharmacognosy and Phytochemistry, 9(6), 312-316.
4. Patil, S. \& Kumar, K.(2014). Characterization and classification of soils of west coast of southern Karnataka. Journal of the Indian Society of Soil Science, 62(4), 408-413.

5. Pinki, S, Chikkaramappa, T., Rajeswari,D. \& Navya, N.C (2017). Characterisation and classification of soil resources of Kumachahalli micro-watershed in Chamarajanagar, Karnataka, India. Int. J Curr. Microbiol. App. Sci., 6(12), 319-329.

6. Ramamurthy, V., Naidu, L.G.K., Kumar, R.S.C., Srinivas, S. \& Hegde, R. (2009). Soil based fertilizer recommendations for precision farming. Current Sci., 97(5), 641-647.

7. Sandhu, O.S. (2017). Morphological and physico-chemical characterization of salt-affected soils of Muktsar district of Punjab. Agropedology, 27(02),131-138.

8. Sarmah, T., Samiron, D., Karmakar, R.M., Tamuly, D. \& Dutta, N. (2019). Characterization and classification of some alluvium-derived rice and associated non-rice soils of Jorhat district of Assam. Journal of the Indian Society of Soil Science, 67(4), 379-388.

9. Sharma., R, Raja, P. \& Baskhar, B.P. (2020). Pedogenesis and Mineralogy of alluvial soils from semi-arid southeastern part of Rajasthan in Aravalli range, India. Journal of the Geological Society of India, 95(1),59-66.

10. Thangasamy, A., Naidu, M.V.S, Ramavatharam, N. \& Reddy, R.C. (2005). Characterization, classification and evaluation of soil resources in Sivagiri micro- watershed of Chittoor district in Andhra Pradesh for sustainable land use planning. J. Indian Soc. Soil Sci., 53, 11-21.

11. Negassa, W. \& Gebrekidan, H. (2003).Forms of phosphorus and status of available micronutrients under different land-use systems of Alfisols in Bako area of Ethiopia. Ethiopian Journal of Natural Resources, 5(1),17-37.

12. Soil Survey Staff (2014). Keys to soil taxonomy, 12th ed. USDA-Natural Resources Conservation Service, Washington, DC. 